\title{
Mountain tourism research. A review
}

\author{
María de la Cruz del Río-Rama ${ }^{1}$, Claudia Patricia Maldonado-Erazo ${ }^{2}$, \\ Amador Durán-Sánchez ${ }^{3}$ and José Álvarez-García ${ }^{4 *}$
}

Received: 15/06/2018 Accepted: 21/12/2018

\footnotetext{
${ }^{1}$ Business Organisation and Marketing Department, Faculty of Busines Administration and Tourism, University of Vigo, 32004 Ourense, Spain. E-mail: delrio@uvigo.es

2 Facultat de Recursos Naturales, Escuela de Ingenieria en Ecoturismo de la Escuela Superior Politécnica de Chimborazo - ESPOCH, Riobamba, Ecuador. E-mail: claudia.maldonado@espoch.edu.ec

${ }^{3}$ Financial Economy and Accounting Department, Faculty of Business, Finance and Tourism, University of Extremadura, 10071 Caceres, Spain. E-mail: amduransan@unex.es

${ }^{4}$ Financial Economy and Accounting Department, Faculty of Business, Finance and Tourism, University of Extremadura, Spain, Avd. de la Universidad, № 47, 10071 Cáceres (Spain). E-mail: pepealvarez@unex.es

* Corresponding author
}

Coordinating editors: Stefano Duglio and Riccardo Beltramo

\begin{abstract}
In recent years, mountain tourism has gradually increased its position among tourists' preferences at international level. The main reason is the strong relationship that man develops with nature and precisely with the mountain, becoming a destination of great tourist influx. An adequate use of these tourist flows results in the development of a sustainable activity, capable of contributing to the improvement of economic conditions in these areas. The objective of this research is to identify and analyse the indexed scientific production on "mountain tourism" in the international databases Scopus and Web of Science, in order to analyse in-depth the current state of this area of study. The work methodology focuses on a bibliometric analysis of the 134 items identified by searching the term "Mountain Tourism". Prior to this analysis, the level of coverage and overlap of the information in both databases was analysed. The results show that Scopus performs a greater coverage of scientific production. In addition, the research is in its exponential growth stage, most researchers are small producers, only 19 have between two and three publications and the European continent is the most prolific in research on mountain tourism. Finally, note that, despite its long coverage over time, more than 40 years, it is an emerging area of study and there are many research lines that must be studied further.
\end{abstract}

Keywords: Mountain Tourism, Bibliometric, Scientific Production, databases.

Citation: Río-Rama, M., C. Maldonado-Erazo, A. Durán-Sánchez and J. Álvarez-García (2019) Mountain tourism research. A review. European Journal of Tourism Research 22, pp. 130-150

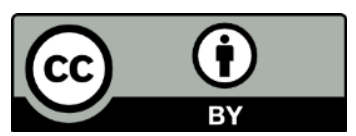

This work is licensed under the Creative Commons Attribution 4.0 International (CC BY 4.0). To view a copy of this license, visit https://creativecommons.org/licenses/by/4.0/ 
Río-Rama, M., C. Maldonado-Erazo, A. Durán-Sánchez and J. Álvarez-García (2019) / European Journal of Tourism Research 22, pp. 130-150

\section{Introduction}

Mountain tourism appeared for the first time as a new type of tourism in The Encyclopedia of Tourism (Jafari, 2003), gradually increasing its positioning within the diversity of forms of tourism, showing a rapid development throughout the world in recent decades (Moss and Godde, 2000; Price, 1992). Mountain areas have currently established themselves as the second most visited tourist destination behind coastal areas (UNEP/PNUMA, 2007), in addition to contributing to $15-20 \%$ of tourism worldwide, which represents between 70 and 90 billion dollars per year (Mohd Taher et al., 2015). For example, tourism in the Alps in 2002 represented between $7 \%$ and $10 \%$ of annual tourist revenues worldwide, a fact that was revealed in the framework of the International Year of the Mountains and also the International Year of Ecotourism.

With regard to this type of tourism, according to Godde et al. (2000), this has always existed, since these spaces were linked by the population to a religious or ancestral connotation (Nepal \& Chipeniuk, 2005; Ortner, 2001), by housing religious sites, which the first pilgrimages moved towards (Godde et al., 2000). Today, the increase in visitor flows, the dissemination of these spaces, the increase in accessibility and the adaptation of the necessary infrastructure make mountain spaces beyond a religious thing; spaces for leisure and sports. Specifically, in the $19^{\text {th }}$ century, mountain areas, especially the Swiss Alps, were the main leisure and free time centres for the wealthy classes of Europe, a situation that spread to the Scandinavian Alps (Flognfeldt \& Tjørve, 2013). With the onset of the $20^{\text {th }}$ century, these areas became an even more attractive destination with the incorporation of new sports and recreational activities (Spanish Tourism Institute, 2009).

The relationship between the mountain and tourism is undeniable, mountains are a place with a large tourist influx, so the its use from a well-focused form of tourism results in the development of a sustainable activity, capable of contributing to the improvement of the economic conditions of these places, which in many cases house low-income populations (Brohman, 1996; Gurung and DeCoursey,
2000; WTO, 2005). In fact, promoting economic development, as well as raising awareness about protecting the environment by promoting mountain tourism was the main issue of the $3^{\text {rd }}$ Euro-Asian Mountain Resorts Conference of the World Tourism Organization (UNWTO, 2017).

According to Tigu (2012), the introduction of tourism in depressed areas enables to reduce inequalities, besides being considered an important source of economic income for the local population. This statement is confirmed by Duglio \& Beltramo (2017), who studied the impact of carrying out sports events in mountain areas. The results of their study show that this form of tourism generates important direct and indirect benefits in the host localities, as well as promoting the sustainability of areas.

There are many spaces designed to develop this form of tourism, taking into account that $24 \%$ of the land surface is mountains; all the continents, as well as extreme ecosystems such as tropical forests, deserts, polar caps are taken into account and included in these calculations (UNEP/PNUMA, 2007). Table 1 shows the geographical distribution of the most important mountainous areas worldwide. In most cases, they are characterized by being areas of difficult access, having a high ecosystem fragility, housing a considerable percentage of the poorest population, as is the case of the Andes, as well as being areas that were forgotten in the past, when making political or economic decisions (Messerli \& Ives, 1997). The European continent hosts the largest number of mountain spaces. According to the data from the Spanish Tourism Institute (2009), the main international destinations for mountain tourism are Austria, Switzerland, France, Italy and Germany.

The literature review on "mountain tourism" leads to the conclusion that there is still no clear and universally accepted definition of this form of tourism. In this sense, Nepal \& Chipeniuk (2005) consider it a space for the development of interactions between nature and man. The appreciation of the landscape and cultural wealth can be included in this broad concept, as well as various recreational and sports activities such as alpine skiing, 
Mountain tourism research. A review.

Table 1. Mountain Ranges of the World

\begin{tabular}{|c|c|c|c|c|c|}
\hline North America & South America & Europe & Africa & Asia & Oceania \\
\hline $\begin{array}{c}\text { Alaska Range } \\
\text { (USA) }\end{array}$ & $\begin{array}{c}\text { Andes } \\
\text { (Argentina, } \\
\text { Chile, Bolivia, } \\
\text { Peru, Ecuador, } \\
\text { Columbia) }\end{array}$ & $\begin{array}{l}\text { Alps } \\
\text { (Central } \\
\text { Europe) }\end{array}$ & $\begin{array}{l}\text { Atlas Mountains } \\
\text { (Morocco, } \\
\text { Algeria) }\end{array}$ & $\begin{array}{l}\text { Altay Mountains } \\
\text { (Mongolia) }\end{array}$ & $\begin{array}{c}\text { Great Dividing } \\
\text { Range } \\
\text { (Australia) }\end{array}$ \\
\hline $\begin{array}{l}\text { Appalachians } \\
\text { Mountains } \\
\text { (USA) }\end{array}$ & & $\begin{array}{l}\text { Caucasus } \\
\text { Mountains } \\
\text { (Ukraine) }\end{array}$ & $\begin{array}{c}\text { Crystal } \\
\text { Mountains } \\
\text { (Gabon, Congo, } \\
\text { Zambia, Angola) }\end{array}$ & $\begin{array}{l}\text { Himalayan } \\
\text { Mountains } \\
\text { (Afghanistan, } \\
\text { Pakistan, India, } \\
\text { Tibet, Nepal, } \\
\text { Kashmir, China) }\end{array}$ & $\begin{array}{l}\text { Southern Alps } \\
\text { (New Zealand) }\end{array}$ \\
\hline $\begin{array}{l}\text { Brooks Range } \\
\text { (USA) }\end{array}$ & & $\begin{array}{l}\text { Kjolen } \\
\text { Mountains } \\
\text { (Norway) }\end{array}$ & $\begin{array}{l}\text { Drakensberg } \\
\text { Mountains } \\
\text { (South Africa) }\end{array}$ & $\begin{array}{l}\text { Tian Shan } \\
\text { (Tajikistan, } \\
\text { Kyrgyzstan) }\end{array}$ & \\
\hline $\begin{array}{c}\text { Coastal } \\
\text { Mountains } \\
\text { (USA-Canada) }\end{array}$ & & $\begin{array}{c}\text { Pyrenees } \\
\text { (France, Spain) }\end{array}$ & $\begin{array}{l}\text { Mitumba } \\
\text { Mountains } \\
\text { (Zambia) }\end{array}$ & $\begin{array}{l}\text { Zagros Mountains } \\
\text { (Iran) }\end{array}$ & \\
\hline $\begin{array}{c}\text { Rocky } \\
\text { Mountains } \\
\text { (USA-Canada) }\end{array}$ & & $\begin{array}{c}\text { Taurus } \\
\text { Mountains } \\
\text { (Turkey) } \\
\text { Thian }\end{array}$ & & & \\
\hline $\begin{array}{l}\text { Sierra Madre } \\
\text { (Mexico) }\end{array}$ & & $\begin{array}{c}\text { Mountains } \\
\text { (Eastern } \\
\text { Europe) } \\
\text { Ural Mountains } \\
\text { (Russia) }\end{array}$ & & & \\
\hline
\end{tabular}

Source: Own elaboration based on the information contained in the United Nations Environment Programme (UNEP/PNUMA, 2007).

mountaineering, climbing, alpinism or any other mountain activity (Gozalo, 2016). For Whitlock et al. (1991), mountain tourism or mountaineering, is just a sector of nature tourism, because this is a term that covers the different activities that can be performed within a natural area. Beedie \& Hudson (2003) consider mountaineering a fragmentation of adventure tourism that has allowed to dominate most of the tourist market. Other authors such as Duglio \& Beltramo (2017) establish that there is a relationship between sports tourism and mountaineering due to the wide range of sports practices it offers. Along the same lines, Bonadonna et al. (2017) identify several studies focused on mountain sports tourism, both winter and summer, as well as sports activities in mountain regions.

Mountain tourism is currently understood as a broad concept that includes: alpine skiing, mountaineering (hiking), climbing, alpinism and other active forms whose activity is in the mountains have been included, such as bicycle touring, canyoning, horse riding, rafting, etc.

In this context, this research aims to analyse and examine the scientific production developed in relation to mountain tourism, in order to observe the evolution in the generation of knowledge about this form of tourism. Therefore, our starting point is the literature available on mountain tourism. There are many approaches followed by researchers ranging from cross-cutting issues such as sustainable development and climate change (Lasanta et al., 2007; Scott et al., 2007; Loibl \& Walz, 2010; Luthe \& Schläpfer, 2011; Morrison \& Pickering, 2013; Bąkowska-Morawska, 2014; Dar et al., 2014; Bonzanigo et al., 2016; Strobl et al., 2015; Bonadonna et al., 2017; Brătucu et al., 2017; Palomo, 2017; Paunović \& Jovanović, 2017; Pronello \& Camusso, 2017; Zhou \& Liu, 2017; Dornier \& Mauri, 2018; Gazzola et al., 2018); to more specialized topics such as the study of experiences (Du Preez \& Lee, 2016; Milman et al., 2017; Milman \& Zehrer, 2018), 

Research 22, pp. 130-150

attitudes of residents and mountaineers's towards tourism development (Muhar et al., 2007; Demirović et al., 2017; Zhang et al., 2017; Tvrtko-Opačić \& Banda, 2018), infrastructure and different markets (Dickson \& Huyton, 2008; Kuščer, 2013; Banki \& Ismail, 2015; Koemle \& Morawetz, 2016; Rakytova \& Tomcikova, 2017; Srđan \& Marija, 2017; Chakraborty, 2018).

However, there is a gap in the conceptualization of this form, which leads to confusing it with other tourism forms such as adventure tourism (Maroudas et al., 2004; Beedie \& Hudson, 2003; Swarbrooke et al., 2003), alpine tourism (Macchiavelli, 2009; Jafari, 2003), nature tourism (Fredman \& Tyrväinen, 2010), as well as ecotourism, active tourism, among others. In all of them, both recreational and sports activities that can be done within mountain spaces are performed.

This article is structured into four sections. After the introduction in which the subject is contextualized, the work methodology is presented. In the third section, the results are shown and in the last section, the conclusions and limitations of the investigation are discussed.

\section{Methodology}

A bibliometric study of the scientific production generated in relation to Mountain Tourism indexed within the international databases Web of Science (WoS) and Scopus is carried out. These bases stand out due to (1) the coverage over time that they provide, (2) the level of detail that exceeds other bases, as well as (3) due to the high-quality standards imposed by the Relative Quality Indices, JCR InCites Journal Citation Report, available for WoS and the SJR Scimago Journal Rank generated by Scopus. Due to all of these characteristics, the use of these two databases does not require further justification (Harzing \& Alakangas, 2016).

This analysis consists of applying several bibliometric indicators, which have been grouped into two categories (Escorcia-Otálora \& Poutou-Piñales, 2008). The activity indicators provide information on quantity, productivity, dispersion, collaboration and networks, among others. On the other hand, the impact indicators provide information on the citation level of the documents, impact factor or immediacy index, $\mathrm{H}$ index, among others. All these indicators arise from mathematical models based on two variables being related (Hubert, 1981), as well as being based on "bibliometric laws" of great relevance such as Lotka's Law, Price's Law, Bradford's Law, as some examples. Table 2 shows the ones used in this investigation.

To apply these indicators, in the first place, it is necessary to build a database that contains detailed information of the documentary units to be analysed. To do so, the documents are tracked through the advanced search of terms; WoS in the field of "TS=Topic" and in Scopus in the field "Article Title, Abstract, Keywords". Search equation: "Mountain Tourism" DOCTYPE (ar) to date $12^{\text {th }}$ March, 2018. A total of 188 articles were obtained (125 Scopus and $63 \mathrm{WoS}$ ). The search has been limited to the most cited documents at present. These documents undergo a peer-review process, which is considered a quality control mechanism (Bryman, 2006); and they are also characterized by the speed of updating and distribution among the scientific community (Martín Vega, 1995). Taking into account all this, books, book chapters and communications in congresses have been excluded from this investigation.

In order to comply with the proposed objective, to see the state of the art in this thematic area, an ad hoc work matrix is built in Microsoft Office Excel with the articles indexed in both databases, debugging it, identifying and deleting duplicate articles. As a final result, the joint work matrix contains 134 articles. For the individual analysis of each of the databases, the original matrices of each of them are maintained.

\section{Traditional Overlapping (TO) and Relative Overlapping}

The use of Meyer's index, Traditional Overlapping (TO) and Relative Overlapping allows to identify the level of overlap of articles indexed in both databases (Gavel \& Iselid, 2008; Pulgarín \& Escalona, 2008). Although the overlapping phenomenon has been known 
Table 2. Search terms in databases

\begin{tabular}{lll}
\hline Activity & - & Productivity per year: total number of articles published per year included in the study. \\
indicators & - & Author productivity: number of articles signed by author. \\
& - & The authors' productivity index: IP= log $\mathrm{N}$, where $\mathrm{N}=$ total of original documents. \\
& - & Lotka index (decimal logarithm of the number of publications): establishes the periodicity of \\
the authors in relation to the publication to a particular topic. The obtaining formula is: $\mathrm{Y}=\mathrm{C}$ \\
/ Xn where $\mathrm{X}$ is the number of publications, and it establishes the frequency of authors with \\
$\mathrm{X}$ publications, while $\mathrm{n}$ and $\mathrm{C}$, are established as constant variables from the field of study \\
analyzed $(\mathrm{n} \approx 2)$. \\
Co-authorship: papers that are produced by two or more authors, this is subdivided into: \\
Co-authorship per institution: documents produced by one or more authors inside \\
or outside the same institution. \\
Co-authorship per country: documents produced by one or more authors inside or \\
outside the same country
\end{tabular}

Productivity by institutions: total number of articles produced by the institution which they belong to in the period of time studied.

Productivity by country: total of articles produced by a country within the established study period.

- Co-author index (number of signatures per paper): quotient between the number of authors and the number of articles.

Index of institutional collaboration: quotient between the number of signatory centres and the number of articles.

\begin{tabular}{|c|c|c|}
\hline $\begin{array}{l}\text { Impact } \\
\text { Indicators }\end{array}$ & - & $\begin{array}{l}\text { Impact factor: SJR or JCR according to the study base that establishes the impact that the } \\
\text { different resources identified within the study have. }\end{array}$ \\
\hline
\end{tabular}

for more than 50 years, it is in the last decade where there has been a greater interest in its study and application (Gavel \& Iselid, 2008).

Meyer's index allows to evaluate the existing coverage in different databases on a specific subject of study (Pulgarín \& Escalona, 2008), based on the determination of the number of repetitions a document has among the chosen databases (Costas et al., 2008; Cañedo Andalia, 1999; Meyer et al., 1983). The calculation of this index gives a weight based on the number of times the document is repeated between the bases, with the greatest weight being given to those documents registered within a single base (weight $=1$ ). As the number of repetitions of a document increases, based on the number of databases used for the comparison, the weight will be reduced gradually for duplicated documents (0.5), tripled documents (0.3), and so on progressively. The value that results from the application of Meyer's index will allow to establish the singularity of each base, the higher the value reached by the index, the greater the originality of the base (Meyer et al., 1983).

$$
\text { Meyer's index }(\mathrm{MI})=\frac{\sum \text { Sources }^{*} \text { Weight }}{\text { Total sources }}
$$

- Traditional Overlapping (TO) determines the percentage of overlap, or the degree of similarity between two bases, in other words, it establishes the similarity that base $A$ has inside base $B$. Therefore, the higher the percentage obtained, the greater the similarity there is (Gluck, 1990).

$$
\mathrm{TO}=100 *\left(\frac{|A \bigcap B|}{|A \bigcup B|}\right)
$$

Relative Overlapping (RO) provides the existing percentage of overlap of one base on another, that is, the coverage that base $A$ has on base B (Bearman \& Kunberger, 1977), considering the weight of overlapping documents with respect to those of a single nature (Costas et al., 2008).

$$
\begin{aligned}
& \text { Overlapping in } \mathrm{A}=100 *\left(\frac{|A \bigcap B|}{|A|}\right), \\
& \text { Overlapping in } \mathrm{B}=100 *\left(\frac{|A \bigcap B|}{|B|}\right)
\end{aligned}
$$

At this point it should be mentioned that the creation algorithms used for Traditional Overlapping (TO) and Relative Overlapping, generate a considerable difference of these with respect to Meyer's index, because the overlapping percentages take into account all 
Río-Rama, M., C. Maldonado-Erazo, A. Durán-Sánchez and J. Álvarez-García (2019) / European Journal of Tourism Research 22, pp. 130-150

the possible unions that can be produced between the analysed databases (Gluck, 1990).

\section{Result}

\section{Overlap of Databases}

Firstly, a correlation analysis is carried out between both databases, in order to observe their relationship level. The linear correlation coefficient is 0.82 , which indicates a strong and direct correlation between Scopus and WoS. It is observed that 54 of the 188 articles (125 Scopus and 63 WoS) are found in both bases, which represents $43 \%$ of Scopus and $86 \%$ of WoS. The remaining articles, 71 of Scopus and 9 of WoS, are classified as single documents since they are present in only of the two bases.

Secondly, Meyer's index (MI) is applied in order to determine the singularity of the bases. Scopus shows a higher singularity index by having a greater number of single documents with an $\mathrm{MI}=0.80$ while in WoS the $\mathrm{MI}=0.60$.

Table 3. Singularity of the Databases

\begin{tabular}{lcccc} 
& \multicolumn{2}{c}{$\begin{array}{c}\% \text { Single } \\
\text { Documents }\end{array}$} & \multicolumn{2}{c}{ Meyer's Index } \\
\hline Databases & Articles & Journals & Articles & Journals \\
Scopus & $56.80 \%$ & $59.74 \%$ & 0.80 & 0.80 \\
WoS & $14.29 \%$ & $16.22 \%$ & 0.60 & 0.58 \\
\hline
\end{tabular}

Source: Authors' own data

On the other hand, the Traditional Overlapping (TO) \% between Scopus and WoS shows a $40.30 \%$ similarity or a disparity of $59.70 \%$ between the bases.

$$
\begin{aligned}
& \text { \%TOSources }=100 *\left(\frac{\mid \text { WoS } \bigcap \text { Scopus } \mid}{\mid \text { WoS } \bigcup \text { Scopus } \mid}\right)=> \\
& \% \text { TO }=100 * 54 /(125+63-54) \\
& =>\% \text { TOSources }=40.30 \%
\end{aligned}
$$

Finally, to establish the percentage coverage of Scopus in relation to WoS and vice versa (Gluck, 1990), Relative Overlapping (RO) was applied:

$\%$ RO scopus $=100 * 54 / 125=43.20 \%$;

$\%$ TO wos $=100 * 54 / 63=85.71 \%$

This result shows that $43.20 \%$ of Scopus is covered by WoS, whereas on the contrary, the
Relative Overlapping (RO) of WoS shows that Scopus covers this base by $85.71 \%$. In this sense, Scopus has a $43 \%$ lower overlap than WoS. This difference can be explained by the coverage over time that each of the bases has, as well as by the indexation policies that in some cases has led to not sharing entirely all the Articles registered within the journals which they have in common (Costas et al., 2008).

\section{Productivity per years}

The coverage over time that is observed considering the two bases goes from 1979 to 2018, a total of 40 years; the first two publications are published in Scopus in 1979 and the first publication in WoS does not appear until the year 2000. The joint work base that groups both databases after debugging and deleting duplicate articles was made up of 134 articles (71 Scopus and 9 WoS, 54 articles contained in both databases). In this period, two of the four stages of the growth process established by Price (1976) can be seen. The first stage, the precursor stage goes from 1979. 2007 (74 articles in 29 years), where slow growth is shown. The second stage begins in 2008 and goes until 2018 (60 articles in 11 years). In this stage, the number of articles has grown exponentially, showing a considerable increase in the initial scientific production in time and quantity. Taking into account the growth curve, it is observed that it will remain constant for the coming years $\left(R^{2}=0.4541\right)$.

A greater coverage of this subject is observed in the Scopus database, both regarding the number of articles published and the number of original articles, Meyer's Index of 0.80 (Figure 2 and 3).

\section{Authoral and co-authorships Productivity}

In relation to the productivity by authors, a total of 276 authors have been identified. 93\% have contributed with a single article, therefore, the author's productivity index is 1.08 . P. Fredman, I. Sacareau and P.W. Williams, with 3 publications each, lead the ranking of the most productive authors. The productivity index is very similar in both databases, 1.09 in Scopus and 1.03 for WoS.

Lotka's Law was applied, which allows to obtain the decimal logarithm of the total num- 


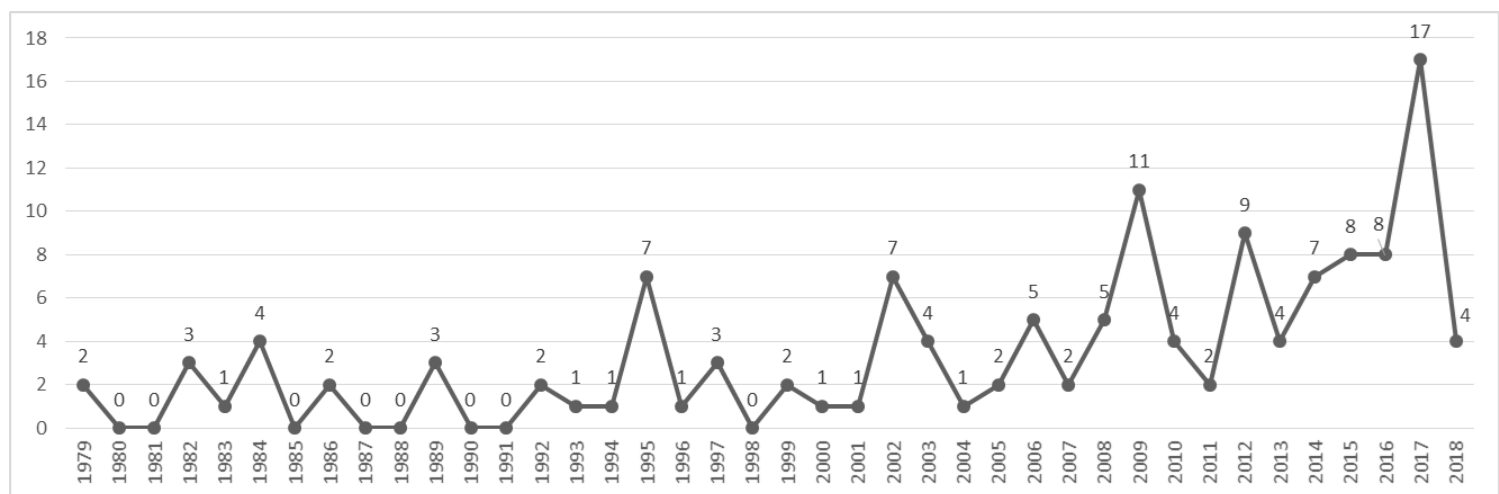

Source: Authors' own data

Figure 1. Trend of publications Scopusu WoS

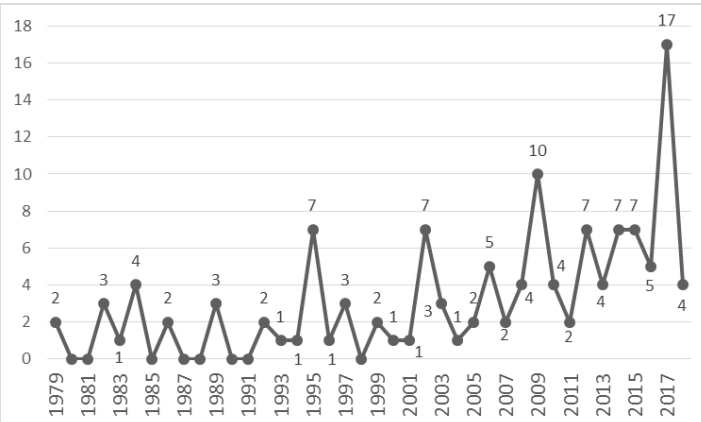

Source: Authors' own data

Figure 2. Trend of publications in Scopus

ber of publications registered by each one of the authors, and from the value obtained, they are grouped into three productivity levels (Lotka, 1926). The initial group is established as small producers, characterized by a single published article and obtaining an index $=0$, where $92 \%$ of Scopus authors and $97 \%$ of WoS are found. The next level corresponds to medium producers, which are characterized by having published between 2 and 9 articles and obtaining an index $>0$, but $<1,8 \%$ of authors of Scopus and $3 \%$ of WoS are identified with this level. Finally, the last level or also called large producers, where authors with 10 or more

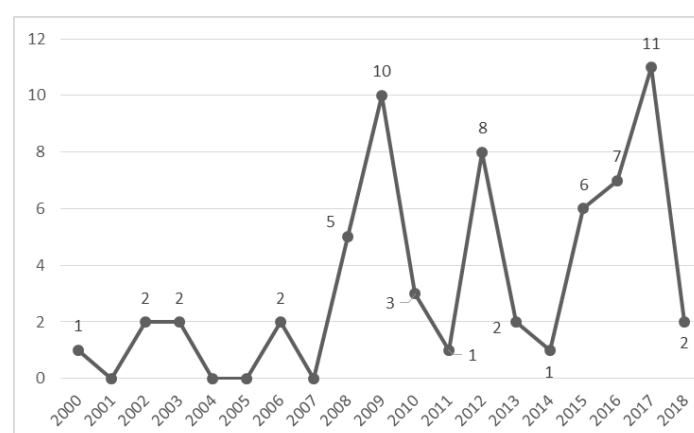

Source: Authors' own data

Figure 3. Trend of publications in WoS

articles are concentrated and with an index $\geq 1$, does not register any authors in this subject analysis. The distribution identified by Lotka's Law corroborates the existence of a large number of authors with a single publication and the predominance of small producers in this area of study.

In the analysis of networks, by applying the coauthorship index or signatures/article index, an average of 2.23 authors per article is observed. $39 \%(52)$ of the articles are signed by a single author.

Table 4. Most productive authors Scopus union WoS

\section{Author}

P. Fredman; I. Sacareau; P.W. Williams

B. Abegg; H. Elsasser; N. Espenbetov; M. Fiebig; T.A. Heberlein; M.

Ikenaga; T. Imangulova; K. Kušcer; T. Lasanta; R. Lessmeister; T.

Luthe; A. Muhar; S.K. Nepal; U. Pröbstl-Haider; F. Ritter; S. Tsiaras;

R. Wyss
No. Articles

Lotka index 
Río-Rama, M., C. Maldonado-Erazo, A. Durán-Sánchez and J. Álvarez-García (2019) / European Journal of Tourism Research 22, pp. 130-150

Table 5. No. of co-authorships

\section{Scopus and WoS}

\section{Classification}

Articles with 1 author

Articles with 2 authors

Articles with 3 authors

Articles with more than

4 authors

Total

$\begin{array}{cc}\begin{array}{c}\text { Number } \\ \text { of } \\ \text { articles }\end{array} & \begin{array}{c}\text { Number of } \\ \text { authorships }\end{array} \\ 52 & 52 \\ 36 & 72 \\ 27 & 81 \\ & \\ 46 & 94 \\ 134 & 299\end{array}$

Source: Authors' own data

Productivity by type of institutions and country It is possible to evaluate the behaviour of the investigation according to the organizations or countries through the analysis of the productivity by type of institution and country (Spinak, 1996). Regarding the productivity per institution, 154 were identified. Universities have the highest number of affiliations with $75 \%$ (115), followed by Research Institutes with $17 \%$ (26). Table 6 shows the ranking of institutions taking into account authors' affiliations. Kazakh Academy of Sports and Tourism of Kazakhstan leads the ranking, followed by the Transylvania University of
Braşov located in Romania. If each one of the bases is taken into account separately, 145 institutions for Scopus and 84 WoS are identified, $75 \%$ (109) belonging to the university typology in Scopus and $77 \%$ (65) in WoS. As for the joint database, a ranking of the institutions was developed according to the affiliations registered by the authors. The university that holds the first place is the Kazakh Academy of Sports and Tourism of Kazakhstan in Scopus and the University of Nebraska of the United States (WoS).

Regarding the productivity per country, Table 7 shows the ranking of the countries according to the affiliations registered by the authors, positioning France with 22 authors, 24 authorships and 17 centres as the leader, followed by the United States with 20 authors, 22 authorships and 10 centres. European countries predominate, which also have the highest number of affiliations of authors, authorships and research centres. If both databases are analysed separately, the United States with 20 authors, 22 authorships and 10 centres is the leader in Scopus and China with 18 authors, 18 authorships and 12 centres in WoS (Table 7).

Table 6. Most productive institutions with authors and authorships

\begin{tabular}{lcc}
\hline \multicolumn{1}{c}{ Institution } & Authors & Authorships \\
\hline Kazakh Academy of Sports and Tourism & 6 & 8 \\
Transylvania University of Braşov & 6 & 6 \\
University of Nebraska & 6 & 6 \\
Simon Fraser University & 5 & 7 \\
Instituto Pirenaico de Ecologia & 5 & 6 \\
Islamic Azad University & 5 & 5 \\
Serbian Spatial Planners Association & 5 & 5 \\
Università degli Studi di Milano & 5 & 5 \\
University in Belgrade & 5 & 5 \\
University in Novi Sad & 5 & 5 \\
Ivane Javakhishvili Tbilisi State University & 4 & 4 \\
Lillehammer University College & 4 & 4 \\
Nanjing University & 4 & 4 \\
North Carolina State University & 4 & 4 \\
Universidad Nacional del Comahue & 4 & 4 \\
Universiti Teknologi MARA & 4 & 4 \\
University of Turin & 4 & 3 \\
Catholic University of Eichstätt-Ingolstadt & 4 & 2 \\
University of Natural Resources and Life Sciences & 4 & 2 \\
University of the Free State & 4 & 2 \\
\hline Sours:Auth' & &
\end{tabular}

Source: Authors' own data 
Table 7. Number of centres, authors and authorships by their country of affiliation

\begin{tabular}{|c|c|c|c|c|c|c|c|c|c|c|c|}
\hline \multicolumn{4}{|c|}{ Scopus and WoS (n=134 articles) } & \multicolumn{4}{|c|}{ Scopus (n=125 articles) } & \multicolumn{4}{|c|}{ WoS (n=63 articles) } \\
\hline Country & $\begin{array}{c}\text { Author } \\
\text { s }\end{array}$ & $\begin{array}{c}\text { Authorship } \\
\text { s }\end{array}$ & $\begin{array}{c}\text { No. } \\
\text { Centres }\end{array}$ & Country & Authors & $\begin{array}{c}\text { Author } \\
\text { ships }\end{array}$ & $\begin{array}{c}\text { No. } \\
\text { Centres }\end{array}$ & Country & $\begin{array}{c}\text { Autho } \\
\text { rs }\end{array}$ & $\begin{array}{c}\text { Author } \\
\text { ships }\end{array}$ & $\begin{array}{c}\text { No. } \\
\text { Centres }\end{array}$ \\
\hline France & 22 & 24 & 17 & U.S.A & 20 & 22 & 10 & China & 18 & 18 & 12 \\
\hline U.S.A & 20 & 22 & 10 & Romania & 20 & 20 & 8 & U.S.A & 18 & 18 & 8 \\
\hline Romania & 20 & 20 & 8 & France & 19 & 21 & 15 & Serbia & 15 & 15 & 5 \\
\hline Serbia & 20 & 20 & 6 & China & 19 & 19 & 13 & \begin{tabular}{|l} 
Italy \\
\end{tabular} & 12 & 12 & 5 \\
\hline China & 19 & 19 & 13 & Serbia & 15 & 15 & 5 & Romania & 12 & 12 & 4 \\
\hline Italy & 16 & 16 & 8 & Canada & 14 & 16 & 9 & France & 9 & 9 & 7 \\
\hline Canada & 14 & 16 & 10 & Italy & 14 & 14 & 6 & Norway & 7 & 7 & 2 \\
\hline Spain & 12 & 13 & 7 & Spain & 9 & 10 & 5 & Canada & 6 & 6 & 4 \\
\hline Austria & 8 & 13 & 7 & Austria & 8 & 13 & 7 & India & 5 & 5 & 4 \\
\hline Kazakhstan & 8 & 10 & 1 & Poland & 8 & 8 & 4 & $\begin{array}{l}\text { German } \\
\text { y }\end{array}$ & 5 & 5 & 4 \\
\hline Poland & 8 & 8 & 4 & Kazakhstan & 8 & 10 & 1 & \begin{tabular}{|l} 
South \\
Africa
\end{tabular} & 5 & 5 & 3 \\
\hline Germany & 7 & 8 & 5 & \begin{tabular}{|l} 
India \\
\end{tabular} & 7 & 7 & 6 & Austria & 5 & 8 & 3 \\
\hline Greece & 7 & 8 & 5 & Greece & 7 & 8 & 5 & Spain & 5 & 5 & 3 \\
\hline India & 7 & 7 & 6 & Norway & 7 & 7 & 2 & Poland & 5 & 5 & 2 \\
\hline Norway & 7 & 7 & 2 & Australia & 6 & 6 & 5 & Iran & 5 & 5 & $\frac{2}{1}$ \\
\hline Switzerland & 6 & 9 & 4 & Switzerland & 6 & 9 & 4 & Australia & 4 & 4 & 3 \\
\hline Australia & 6 & 6 & 5 & Germany & 5 & 6 & 4 & $\begin{array}{l}\text { Switzerla } \\
\text { nd }\end{array}$ & 4 & 4 & 2 \\
\hline South Africa & 5 & 5 & 3 & South Africa & 5 & 5 & 3 & $\begin{array}{l}\text { Argentin } \\
a\end{array}$ & 4 & 4 & 1 \\
\hline Iran & 5 & 5 & 1 & Nepal & 4 & 4 & 4 & \begin{tabular}{|l} 
Malaysia \\
\end{tabular} & 4 & 4 & 1 \\
\hline Nepal & 4 & 4 & 4 & U.K.. & 4 & 4 & 3 & Sweden & 3 & 4 & 1 \\
\hline U.K.. & 4 & 4 & 3 & Argentina & 4 & 4 & 1 & Georgia & 3 & 3 & 1 \\
\hline Argentina & 4 & 4 & 1 & Malaysia & 4 & 4 & 1 & Albania & 2 & 2 & 2 \\
\hline Georgia & 4 & 4 & 1 & Georgia & 4 & 4 & 1 & U.K. & 2 & 2 & 2 \\
\hline Malaysia & 4 & 4 & 1 & Kyrgyzstan & 3 & 3 & 3 & Greece & 2 & 3 & 1 \\
\hline Sweden & 3 & 5 & 1 & Portugal & 3 & 3 & 2 & Slovenia & 2 & 2 & 1 \\
\hline Slovenia & 3 & 4 & 1 & Russia & 3 & 3 & 2 & $\begin{array}{l}\text { Taiwan } \\
\end{array}$ & $\frac{2}{1}$ & 1 & 1 \\
\hline Kyrgyzstan & 3 & 3 & 3 & Morocco & 3 & 3 & 1 & Croatia & 1 & 1 & 1 \\
\hline Portugal & 3 & 3 & 2 & Indonesia & 3 & 3 & 1 & Total & 164 & 169 & 84 \\
\hline Russia & 3 & 3 & 2 & Slovenia & 3 & 4 & 1 & & & & \\
\hline Indonesia & 3 & 3 & 1 & Sweden & 3 & 5 & 1 & & & & \\
\hline Morocco & 3 & 3 & 1 & Japan & 2 & 3 & 2 & & & & \\
\hline Japan & 2 & 3 & 2 & Albania & 2 & 2 & 2 & & & & \\
\hline Albania & 2 & 2 & 2 & Croatia & 2 & $\frac{L}{2}$ & 2 & & & & \\
\hline Croatia & 2 & 2 & 2 & Slovakia & 2 & 2 & 1 & & & & \\
\hline Slovakia & 2 & 2 & 1 & Taiwan & 1 & 1 & 1 & & & & \\
\hline $\begin{array}{l}\text { Bosnia and } \\
\text { Herzegovina }\end{array}$ & 1 & 1 & 1 & Thailand & 1 & 1 & 1 & & & & \\
\hline Finland & 1 & 1 & 1 & $\begin{array}{l}\text { Bosnia and } \\
\text { Herzegovina }\end{array}$ & 1 & 1 & 1 & & & & \\
\hline Taiwan & 1 & 1 & 1 & Finland & 1 & 1 & 1 & & & & \\
\hline Thailand & 1 & 1 & 1 & $\begin{array}{l}\text { Without } \\
\text { affiliation }\end{array}$ & 6 & 6 & 0 & & & & \\
\hline $\begin{array}{l}\text { Without } \\
\text { affiliation }\end{array}$ & 6 & 6 & 0 & Total & 256 & 279 & 144 & & & & \\
\hline Total & 276 & 299 & 154 & & & & & & & & \\
\hline
\end{tabular}

Source: Authors' own data

To determine the collaboration processes in this area of study, only articles written by two or more authors, i.e., $61 \%(82)$ of the articles that make up the joint base, are taken into account. Within this group, it can be seen that in $71 \%$ (58) of the articles, the authors who sign them are from the same country, there are international participations in $27 \%$ (22), whereas $2 \%(2)$ of the articles do not have any information to establish the type of collaboration they have. In the case of national collaborations, $67 \%$ (39) of the articles are signed by authors from the same institution, and the remaining $33 \%$ (19) are signed by 
authors from different institutions, but from the same country. Regarding international collaboration, $95 \%$ (21) of the articles are signed by authors of several institutions based in different countries and only $5 \%$ (1) of the articles have been written under the collaboration of authors of the same university, but with headquarters in different areas of the world.

If both bases are analysed separately, there are $62 \%(77)$ of articles in Scopus and $76 \%$ (48) in WoS, written by two or more authors. The results obtained show that $69 \%$ (53) of the articles in Scopus are written with the participation of authors from the same country, $29 \%$ (22) have international participation, while $3 \%$ (2) of the Articles do not have any information to establish the type of collaboration they have. In the case of WoS, it is observed that $75 \%$ (36) of the articles are signed by authors from the same country, and the remaining $25 \%$ (3) are signed by authors from different countries.

\section{Journals}

In the analysis of the journals where the articles are published, it is observed that the 134 articles have been published in 83 journals, which represents a dispersion index of 1.61 articles/journals. Thus, 45\% (60 journals) have published a single article on this area of study. Taking into account the ranking of the most prolific journals, Revue de Geographie Alpine (11 articles) holds the first position, whose publication country is France (JCR index of 0.365, Q4). Mountain Research and Development (9 articles) published in the United States (Q2 with an index of 0.441 in The SCImago Journal \& Country Rank) is in the second position. If both databases are analysed separately, the dispersion index in Scopus is 1.62 articles/journals and 1.70 articles/journals in WoS. Thus, 70\% (54 journals) of Scopus and $76 \%$ (28 journals) of WoS have published a single article on this area of study. Taking into account the ranking of the most prolific journals, Mountain Research and Development in Scopus is in the first position and the leading journal in WoS is Revue de Geographie Alpine.

According to Bradford's Law, it is possible to observe the presence of a unique behaviour in which the articles are concentrated in a small number of journals (Bradford, 1934). In the case of this study area, $51 \%(68)$ of the articles have been published in $24 \%$ (20) of the journals (3.88 articles/journals). In Scopus, $57 \%(71)$ of the articles have been published in $30 \%(23)$ of the journals (3.88 articles/journals) and in WoS, $56 \%$ (35) of the articles have been published in $24 \%$ (9) of the journals (3.40 articles/journals). Therefore, it is observed that there is a core of journals that contain the majority of articles published on the subject.

In relation to the quality indices, taking into account the SCImago Journal Rank (SJR) indices of Scopus and the JCR of WoS, it is observed that $25 \%$ of the articles are published in journals with a Q2 impact index, followed by $22 \%$ that are published in Q4 journals.

\section{Study Areas}

Both Scopus and WoS show a strong multidisciplinary nature, and although the classification of areas is different in both databases, many similarities are observed, an element which allows for comparison. The areas in which most publications are grouped in Scopus is Social Sciences with $46 \%$ of the articles, followed by Business, Management and Accounting (24\%). In WoS, Environmental Sciences \& Ecology (41\%) and Social Sciences - Other Topics (22\%).

Regarding the categories, Geography, Planning and Development with $24 \%$ of the articles, followed by Tourism, Leisure and Hospitality Management (18\%) are the two main categories in Scopus. In WoS, they are Environmental Sciences (30\%) and Hospitality, Leisure, Sport \& Tourism (22\%).

\section{Content analysis}

The content analysis enabled to identify (1) the research lines or thematic areas followed by the authors, and (2) the geographical areas of the researchers, which coincides mainly with the geographical area where the study is carried out (the traditional model of five continents of the UN, Africa, America, Asia, Europe and Oceania was followed). This analysis showed the research trends on this area of study taking into account a geographical criterion. 
Mountain tourism research. A review.

Table 8. Journals with the highest number of articles

\begin{tabular}{|c|c|c|c|c|c|c|c|c|c|c|c|}
\hline \multicolumn{4}{|c|}{ Scopus and WoS ( $n=134$ articles) } & \multicolumn{4}{|c|}{ Scopus ( $n=125$ articles) } & \multicolumn{4}{|c|}{ WoS ( $n=63$ articles) } \\
\hline Journals & $\begin{array}{c}\text { No. } \\
\text { Articles }\end{array}$ & $\%$ & Quartile & Journals & $\begin{array}{c}\text { No. } \\
\text { Articles }\end{array}$ & $\%$ & Quartile & Journals & \begin{tabular}{|c|} 
No. \\
Articles \\
\end{tabular} & $\%$ & Quartile \\
\hline $\begin{array}{l}\text { Revue de Geographie } \\
\text { Alpine }\end{array}$ & 11 & 8.2 & Q4 & & & & & & & & \\
\hline $\begin{array}{l}\text { Mountain Research and } \\
\text { Development }\end{array}$ & 9 & 6.7 & Q2 & \begin{tabular}{|l|} 
Mountain \\
Research and \\
Development \\
\end{tabular} & 9 & 7.2 & Q2 & $\begin{array}{l}\text { Revue de } \\
\text { Geographie } \\
\text { Alpine }\end{array}$ & 7 & 11.1 & Q4 \\
\hline $\begin{array}{l}\text { Sustainability } \\
\text { (Switzerland) }\end{array}$ & 5 & 3.7 & Q2 & $\begin{array}{l}\text { Revue de } \\
\text { Geographie } \\
\text { Alpine }\end{array}$ & 8 & 6.4 & Q4 & \begin{tabular}{|l|} 
Mountain \\
Research and \\
Development \\
\end{tabular} & 7 & 11.1 & Q4 \\
\hline \begin{tabular}{|l} 
Journal of Sustainable \\
Tourism \\
\end{tabular} & 4 & 3.0 & Q1 & $\begin{array}{l}\text { Sustainability } \\
\text { (Switzerland) }\end{array}$ & 5 & 4.0 & Q2 & Sustainability & 5 & 7.9 & Q2 \\
\hline $\begin{array}{l}\text { Tourism Recreation } \\
\text { Research }\end{array}$ & 4 & 3.0 & -- & \begin{tabular}{|l} 
Tourism \\
Recreation \\
Research \\
\end{tabular} & 4 & 3.2 & -- & $\begin{array}{l}\text { Journal of } \\
\text { Sustainable } \\
\text { Tourism } \\
\end{array}$ & 4 & 6.3 & Q1 \\
\hline Anatolia & 3 & 2.2 & Q2 & \begin{tabular}{|l} 
Journal of \\
Sustainable \\
Tourism \\
\end{tabular} & 4 & 3.2 & Q1 & \begin{tabular}{|l} 
Journal of \\
Mountain \\
Science \\
\end{tabular} & 3 & 4.8 & Q4 \\
\hline Geografija & 3 & 2.2 & -- & Geografija & 3 & 2.4 & -- & $\begin{array}{l}\text { Metalurgia } \\
\text { International }\end{array}$ & 3 & 4.8 & Q4 \\
\hline $\begin{array}{l}\text { ICIMOD Discussion } \\
\text { Paper, MEI Series }\end{array}$ & 3 & 2.2 & -- & $\begin{array}{l}\text { ICIMOD } \\
\text { Discussion } \\
\text { Paper, MEI } \\
\text { Series } \\
\end{array}$ & 3 & 2.4 & -- & Ambio & 2 & 3.2 & Q1 \\
\hline $\begin{array}{l}\text { Journal of Mountain } \\
\text { Science }\end{array}$ & 3 & 2.2 & Q2 & $\begin{array}{l}\text { Metalurgia } \\
\text { International }\end{array}$ & 3 & 2.4 & Q4 & $\begin{array}{l}\text { Journal of } \\
\text { Outdoor } \\
\text { Recreation and } \\
\text { Tourism } \\
\end{array}$ & 2 & 3.2 & -- \\
\hline Metalurgia International & 3 & 2.2 & Q4 & \begin{tabular}{|l|} 
Journal of \\
Mountain \\
Science \\
\end{tabular} & 3 & 2.4 & Q2 & $\begin{array}{l}\text { Tourism } \\
\text { Economics }\end{array}$ & 2 & 3.2 & Q3 \\
\hline Ambio & 2 & 1.5 & Q1 & Anatolia & 3 & 2.4 & Q2 & In summary: & \begin{tabular}{|c|} 
Total \\
Articles \\
\end{tabular} & & on total \\
\hline Cuadernos de Turismo & 2 & 1.5 & Q4 & $\begin{array}{l}\text { Japanese } \\
\text { Journal of } \\
\text { Human } \\
\text { Geography }\end{array}$ & 2 & 1.6 & -- & $\begin{array}{l}28 \text { Journals with } \\
1 \text { article }\end{array}$ & 28 & & 44.4 \\
\hline Erdkunde & 2 & 1.5 & Q3 & $\begin{array}{l}\text { Geographica } \\
\text { Pannonica }\end{array}$ & 2 & 1.6 & Q3 & & & & \\
\hline Espacios & 2 & 1.5 & Q3 & $\begin{array}{l}\text { Cuadernos de } \\
\text { Turismo }\end{array}$ & 2 & 1.6 & Q4 & & & & \\
\hline Geographica Pannonica & 2 & 1.5 & Q3 & $\begin{array}{l}\text { Scandinavian } \\
\text { Journal of } \\
\text { Hospitality and } \\
\text { Tourism } \\
\end{array}$ & 2 & 1.6 & Q2 & & & & \\
\hline $\begin{array}{l}\text { Geojournal of Tourism } \\
\text { and Geosites }\end{array}$ & 2 & 1.5 & Q3 & $\begin{array}{l}\text { Journal of } \\
\text { Outdoor } \\
\text { Recreation and } \\
\text { Tourism } \\
\end{array}$ & 2 & 1.6 & Q3 & & & & \\
\hline $\begin{array}{l}\text { Japanese Journal of } \\
\text { Human Geography }\end{array}$ & 2 & 1.5 & -- & $\begin{array}{l}\text { Tourism } \\
\text { Management } \\
\text { Perspectives }\end{array}$ & 2 & 1.6 & Q1 & & & & \\
\hline \begin{tabular}{|l|} 
Journal of Outdoor \\
Recreation and Tourism
\end{tabular} & 2 & 1.5 & Q3 & Espacios & 2 & 1.6 & Q3 & & & & \\
\hline $\begin{array}{l}\text { Scandinavian Journal of } \\
\text { Hospitality and Tourism }\end{array}$ & 2 & 1.5 & Q2 & Erdkunde & 2 & 1.6 & Q3 & & & & \\
\hline Tourism Economics & 2 & 1.5 & Q1 & $\begin{array}{l}\text { Geojournal of } \\
\text { Tourism and } \\
\text { Geosites }\end{array}$ & 2 & 1.6 & Q3 & & & & \\
\hline Tourism Geographies & 2 & 1.5 & Q1 & Ambio & 2 & 1.6 & Q1 & & & & \\
\hline Tourism Management & 2 & 1.5 & Q1 & \begin{tabular}{|l|} 
Tourism \\
Management
\end{tabular} & 2 & 1.6 & Q1 & & & & \\
\hline $\begin{array}{l}\text { Tourism Management } \\
\text { Perspectives }\end{array}$ & 2 & 1.5 & Q1 & $\begin{array}{l}\text { Tourism } \\
\text { Economics }\end{array}$ & 2 & 1.6 & Q1 & & & & \\
\hline In summary: & $\begin{array}{c}\text { Total } \\
\text { Articles }\end{array}$ & & on total & $\begin{array}{l}\text { Tourism } \\
\text { Geographies }\end{array}$ & 2 & 1.6 & Q1 & & & & \\
\hline $\begin{array}{l}60 \text { Journals with } 1 \text { article } \\
\text { each }\end{array}$ & 60 & & 44.8 & In summary: & \begin{tabular}{|c|} 
Total \\
Articles
\end{tabular} & & on total & & & & \\
\hline & & & & \begin{tabular}{|l|}
54 Journals \\
with 1 article \\
each
\end{tabular} & 54 & & 43.2 & & & & \\
\hline
\end{tabular}


Firstly, three main lines of research were identified:

- Climate changes. Study of the climate changes that are taking place in mountain areas, from a tourist perspective.

- Sustainable development. It groups research that studies aspects related to the economic, social and environmental dimension in the sustainable development of the tourism activity.

- Tourist system. Four work approaches:

(1) Demand analysis: tourist flows, tourist experience of visitors, tourist expenditure, motivations and perception of tourists about the spaces visited and the demand for sports activities in these spaces.

(2) Supply analysis: it includes studies in which the situation of service providers is analysed, as well as the cooperation between the different supply elements. Aspects such as the design and implementation of technologies for the management and improvement of information and tourism promotion, human talent, the level of development of the areas that have opted for the offer of mountain tourism are also dealt with.

(3) Destination management: it groups studies that analyse the potential of mountain areas, policies for the exploitation and use of mountain areas for tourism purposes, as well as the identification of the impacts that arise from the introduction and development of the tourist activity in mountain destinations.

(4) Conceptualization: it establishes the reference framework for the understanding of mountain tourism.

Secondly, the research is analysed considering the researcher affiliation criterion to one of the four continents considered. The aim is to observe if there is a predominance of studies by line and continent.

Europe: this continent is positioned as the main reference in the development of studies in relation to mountain tourism, with 78 studies; France is the country of affiliation with the highest number of studies, with 11 altogether. With regard to the lines of research, studies on the climate change that is taking place within mountain areas from the tourist activity perspective (Varley \& Medway, 2011) are observed, others deal with the environmental degradation of natural resources, among which water stands out (Younes et al., 2002). Tsiaras \& Andreopoulou (2015) address sustainable development as a multilateral concept in which mountain tourism management is integrated as an important pillar and Fredman (2008) identifies the determinants of tourist expenditure.

- Asia: it is the second continent where the greatest number of researchers is concentrated. Leading countries include Nepal (9), India (6) and China (4). Regarding the research lines, studies focused mainly on the tourism system are observed; Destination management and its tourism potential (Cappucci et al., 2015), demand analysis when measuring tourism flows (Mohd Taher et al., 2015). Other studies address the sustainable development of the areas that have been or will be designed for mountain tourism activities (Cole \& Sinclair, 2002).

- America: it is the third continent in the ranking. The country with the highest concentration is Canada (3), followed by the United States (2) and Argentina (1). Demand studies are carried out through tourism flows to mountainous areas (Kelly et al., 2006) and on the management of growth and depopulation in the mountains (Gonzalez et al., 2009).

- Africa: researchers are mainly affiliated to Morocco (3) and South Africa (3). The studies address the management of the destination; determine the tourist potential that the study areas have for the development of new mountain tourism destinations (Linde \& Grab, 2008).

- Oceania: it is the last continent taking into account the ranking developed. Studies developed exclusively in Australia are identified (2); Pickering \& Buckley (2010) address climate change and Tonkin (1995) management policies of this form of tourism.

In addition, a total of 8 multicontinental studies that deal with the sustainable development of mountain spaces were identified. Hereafter, due to their relevance, studies related to the European continent are collected.

\section{Conclusions}

In order to comply with the proposed objective, a bibliometric analysis was carried out that allowed to identify the profile of the area under study "Mountain Tourism" (evolution, 
researchers, affiliation, etc). In this research, two databases were used and a study on their overlap and coverage was carried out. The findings point out that the Scopus database has a greater coverage of the scientific production on this area under study. In this sense, Scopus covers $85.71 \%$ of WoS, since it is observed that 54 of the 188 articles indexed in both databases are duplicated and 71 articles are classified as single in Scopus and 9 in WoS.

After a slow growing first stage from 1979 to 2007 , the research is currently immersed in a second stage of exponential growth (60 articles in 11 years), and taking into account the growth curve $\left(R^{2}=0,4541\right)$. it is expected to remain constant in the coming years.

The analysis shows that most researchers in this area are part of the group called small producers if Lotka's Law or the productivity of the authors (Lotka, 1926) is considered. $93 \%$ of the authors (256 of a total of 276) published a single article, and the rest, 19 authors have between 2 and 3 publications. The most productive authors with 3 publications are P. F redman, I. Sacareau; P.W. Williams, The productivity index is 1.08 articles. A very high number of papers were signed by a single author (38\%), the average is 2.23 signatures per paper.

Table 9. Areas of study in the European Continent

\begin{tabular}{|c|c|c|c|}
\hline $\begin{array}{l}\text { General } \\
\text { Line }\end{array}$ & Specific Line & No. Articles & Authors \\
\hline 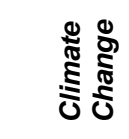 & Climate Change & 9 & $\begin{array}{l}\text { Djordjevic et al. (2016), Pröbstl-Haider et al. (2016), } \\
\text { Stojsavljević et al. (2016), Wyss et al. (2014), Luthe et al. } \\
\text { (2012), Ritter et al. (2012), Varley \& Medway (2011), } \\
\text { Błazejczyk \& Sitek (2003), Abegg \& Elsasser (1996) }\end{array}$ \\
\hline \multirow{3}{*}{ 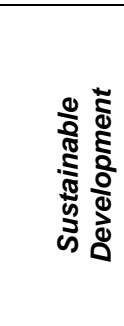 } & $\begin{array}{l}\text { Environmental } \\
\text { Degradation }\end{array}$ & 2 & Storch \& Leidenberger (2003), Younes et al. (2002) \\
\hline & $\begin{array}{l}\text { Sustainable } \\
\text { Development }\end{array}$ & 10 & $\begin{array}{l}\text { Bonadonna et al. (2017), Brătucu et al. (2017), Paunović \& } \\
\text { Jovanović (2017), Tsiaras (2017), Tsiaras \& Andreopoulou } \\
\text { (2015), Minciu et al. (2009), Saz Gil \& Carus Ribalaygua } \\
\text { (2008), Ikenaga (2001), Ikenaga (1999), Stadelbauer (1983) }\end{array}$ \\
\hline & $\begin{array}{l}\text { Growth Management } \\
\text { and Depopulation }\end{array}$ & 3 & Kohler et al. (2017), Galvani (1993), Mazuel (1992) \\
\hline \multirow{4}{*}{$\begin{array}{l}5 \\
\Phi \\
\text { के } \\
\frac{5}{5} \\
\frac{5}{5}\end{array}$} & Analysis of the offer & 23 & $\begin{array}{l}\text { Tvrtko-Opačić \& Banda (2018), Kuščer et al. (2017), Czakon } \\
\text { \& Czernek (2016), Suarez Botas (2016), Pawłowska et al. } \\
\text { (2015), Tizzoni (2015), Băltăreţu (2014), Tofan \& Niţă } \\
\text { (2014), Cousquer \& Beames (2013), Flognfeldt \& Tjørve } \\
\text { (2013), Dissart (2012), George-Marcelpoil \& Francois } \\
\text { (2012), Krištofić (2010), Nistor et al. (2010), Ritter et al. } \\
\text { (2010), Kaltenborn et al. (2008), Bourdeau et al. (2002), } \\
\text { Heberlein et al. (2002), Petit (2002), Frosch \& Elsasser } \\
\text { (1989), Semerdzhiev \& Dancheva (1984), B'Chvarov (1982), } \\
\text { Hadzhinikolov (1982) }\end{array}$ \\
\hline & Analysis of demand & 10 & $\begin{array}{l}\text { Frochot et al. (2017), Kortoci \& Kortoci (2017), Milman et al. } \\
\text { (2017), Fuchs et al. (2014), Silva et al. (2013), Bitsani \& } \\
\text { Kavoura (2012), Garavaglia et al. (2012), Nicolae \& Florin } \\
\text { (2009), Fredman (2008), Fredman \& Heberlein (2005) }\end{array}$ \\
\hline & Conceptualization & 1 & Macchiavelli (2009) \\
\hline & $\begin{array}{l}\text { Destination } \\
\text { Management }\end{array}$ & 20 & $\begin{array}{l}\text { Rakytova \& Tomcikova (2017), Nikolić et al. (2015), Lasanta } \\
\text { et al. (2014), Rodriguez (2012), Skenderovic et al. (2012), } \\
\text { Timotin et al. (2009), Lasanta et al. (2007), Boudières } \\
\text { (2006), Duboeuf (2006), Mechukaev \& Mechukaev (2006), } \\
\text { Marín-Yaseli \& Martínez (2003), Tchistiakova \& Cabanne } \\
\text { (1997), Cerutti (1995), Gaudard (1995), Lepovitz (1989), } \\
\text { Herbin (1986), Penz (1984), Vlad \& Truti (1984), De } \\
\text { Reparaz (1982), Lichtenberger (1979) }\end{array}$ \\
\hline
\end{tabular}


Universities are the institutions with the highest number of affiliations, with $75 \%$. Kazakh Academy of Sports and Tourism of Kazakhstan leads the ranking, followed by the Transylvania University of Braşov located in Romania. If productivity by country based on the affiliations registered by the authors is observed, France is positioned as the leader followed by the United States. European countries predominate in the group of countries, which also have the highest number of affiliations of authors, authorships and research centres. On the other hand, $71 \%$ of articles with more than two signatories are written in collaboration with authors from the same country. In the case of national collaborations, $67 \%$ of the articles are signed by authors of the same institution.

The analysis of the study areas makes it possible to identify the European continent as the most prolific in research on mountain tourism, partly due to having a greater number of mountain ranges, tourist infrastructures and greater accessibility, followed by Asia, being the Himalayas the main destination. Regarding the lines of research followed by the different authors, the study of the sustainable development of spaces, the climate changes that have caused the degradation of the spaces and the potentiality of certain areas due to their positioning as destinations for mountain tourism predominate. This analysis confirms that it is an emerging area of study, with many research lines that must be studied further such as the overcrowding in destinations, load capacity, migration or depopulation of mountain areas, policies on destination management, etc. These approaches are followed by a small number of articles, and it is necessary to progress in the generation of knowledge at the level of all continents.

In summary, research is very necessary to know and deepen the phenomenon of "Mountain Tourism" at the management level, with the aim of providing assistance, to mountain tour operators and all the entities involved, in the development of the activity tourism in mountain areas, so that these can improve their social and environmental performance. The growth in the number of visitors to mountain areas provides important advantages to local communities in terms of job creation, income, etc. However, there are also many dangers that come from the possible impacts of mountain tourism and its activities. In this sense, according to UNEP / PNUMA (2007) it is necessary to observe good practices in key aspects related to mountain tourism: good business practices, good environmental practices and good practices of specific tourism activities. In this context, research is very necessary.

The main limitation of the study is related to the lack of a clear conceptualization of the concept, which generates an ambiguity about what mountain tourism comprises. This ambiguity is reflected in the authors' indexing words. Therefore, we chose to use a single search term "Mountain Tourism" in order to delimit the area under study with greater precision. A second limitation is related to the selected databases. In this sense, the geographic coverage identified in the analysis of the study areas suggests that future research should expand the databases and consider others such as Scielo, Latindex, Emerald, enabling to identify a greater number of studies.

\section{References}

Abegg, B., \& Elsasser, H. (1996). Climate, weather, and tourism in the Swiss alps. Geographische Rundschau, 48(12), 737742.

Bąkowska-Morawska, U. (2014). Ecological approach presented by managers of hospitality services in the Karkonosze Mountains. The identification of activities reducing negative environmental impacts. Procedia-Social and Behavioral Sciences, 151, 16-28.

Băltăreţu, A. (2014). Spatial Features of Mountain Areas. Quality - Access to Success, 15(2), 132-139.

Banki, M. B., \& Ismail, H. N. (2015). Understanding the characteristics of family owned tourism micro businesses in mountain destinations in developing countries: evidence from Nigeria. Tourism Management Perspectives, 13, 18-32.

B'Chvarov, M. (1982). The conditions and problems of mountain tourism in Bulgaria. Geografija, 7, 1-5.

Bearman, T.C., \& Kunberger, W.A. (1977). A study of coverage overlap among fourteen 
major science and technology abstracting and indexing services. Philadelphia: National Federation of Abstracting and Indexing Services.

Beedie, P., \& Hudson, S. (2003). Emergence of mountain-based adventure tourism. Annals of Tourism Research, 30(3), 625643.

Bitsani, E., \& Kavoura, A. (2012). Accessibility versus advertising for mountain tourism: the case of Nafpaktia. Tourismos, 7(2), 217-236.

Błazejczyk, K., \& Sitek, M. (2003). The temperature felt by tourists in the mountains in summer. Dokumentacja Geograficzna, (29), 61-64.

Bonadonna, A., Giachino, C., \& Truant, E. (2017). Sustainability and Mountain Tourism: The Millennial's Perspective. Sustainability, 9(1219), 1-15.

Bonzanigo, L., Giupponi, C., \& Balbi, S. (2016). Sustainable tourism planning and climate change adaptation in the Alps: A case study of winter tourism in mountain communities in the Dolomites. Journal of Sustainable Tourism, 24(4), 637-652.

Boudières, V. (2006). The notion of risk governance: an application in terms of the vulnerability of mountain tourism areas. Revue de Géographie Alpine, 94(1), 5374.

Bourdeau, P., Corneloup, J., \& Mao, P. (2002). Adventure sports and tourism in the French mountains: Dynamics of change and challenges for sustainable development. Current Issues in Tourism, 5(1), 22-32.

Bradford, S. C. (1934). Sources of information on specific subjects. Engineering, 137, 8586.

Brătucu, G., Băltescu, C. A., Neacșu, N. A., Boșcor, D., Tierean, O. M., \& Madar, A. (2017). Approaching the Sustainable Development Practices in Mountain Tourism in the Romanian Carpathians. Sustainability, 9(11), 1-20.

Brohman, J. (1996). New directions in tourism for third world development. Annals of Tourism Research, 23(1), 48-70.

Bryman, A. (2006). Integrating quantitative and qualitative research: how is it done? Qualitative Research, 6(1), 97-113.
Cañedo Andalia, R. (1999). Estudios de solapamiento en la selección de las publicaciones seriadas y las bases de datos. ACIMED, 7, 164-170.

Cappucci, M., Pavliashvili, N., \& Zarrilli, L. (2015). New trends in mountain and heritage tourism: The case of upper svaneti in the context of Georgian tourist sector. GeoJournal of Tourism and Geosites, 15(1), 67-80.

Cerutti, A. (1995). The alpine glaciers as factors of economic wealth. Geografia Fisica e Dinamica Quaternaria, 18(2), 211215.

Chakraborty, A. (2018). Japan's mountain tourism at a crossroads: Insights from the North Japan Alps. Tourism Planning \& Development, 15(1), 82-88.

Cole, V., \& Sinclair, A. J. (2002). Measuring the ecological footprint of a Himalayan tourist center. Mountain Research and Development, 22(2), 132-141.

Costas, R., Moreno, L., \& Bordons, M. (2008). Solapamiento y singularidad de MEDLINE, WoS e IME para el análisis de la actividad científica de una región en Ciencias de la Salud. Revista Española de Documentación Científica, 31(3), 327-343.

Cousquer, G. O., \& Beames, S. (2013). Professionalism in mountain tourism and the claims to professional status of the International Mountain Leader. Journal of Sport \& Tourism, 18(3), 185-215.

Czakon, W., \& Czernek, K. (2016). The role of trust-building mechanisms in entering into network coopetition: The case of tourism networks in Poland. Industrial Marketing Management, 57, 64-74.

Dar, R. A., Rashid, I., Romshoo, S. A., \& Marazi, A. (2014). Sustainability of winter tourism in a changing climate over Kashmir Himalaya. Environmental Monitoring and Assessment, 186(4), 2549-2562.

De Reparaz, A. (1982). Investments in the mountains of Provence. Provence Historique, 32, 391-407.

Demirović, D., Radovanović, M., Petrović, M. D., Cimbaljević, M., Vuksanović, N., \& Vuković, D. B. (2017). Environmental and Community Stability of a Mountain Destination: An Analysis of Residents' Perception. Sustainability, 10(1), 1-16. 
Río-Rama, M., C. Maldonado-Erazo, A. Durán-Sánchez and J. Álvarez-García (2019) / European Journal of Tourism Research 22, pp. 130-150

Dickson, T.J., \& Huyton, J. (2008). Customer service, employee welfare and snowsports tourism in Australia. International Journal of Contemporary Hospitality Management, 20(2), 199-214.

Dissart, J.C. (2012). Building capabilities and territorial resources in mountain tourist areas. Case study in Oisans. Revue de Géographie Alpine, 100(2), 1-10.

Djordjevic, D., Secerov, V., Filipovic, D., Lukic, B., \& Jeftic, M. R. (2016). The impact of climate change on the planning of mountain tourism development in Serbia: case studies of kopaonik and zlatibor. Fresenius Environmental Bulletin, 25(11), 5027-5034.

Dornier, R., \& Mauri, C. (2018). Overview: tourism sustainability in the Alpine region: the major trends and challenges. Worldwide Hospitality and Tourism Themes, 10(2), 136-139.

Du Preez, M., \& Lee, D. E. (2016). The economic value of the Trans Baviaans mountain biking event in the Baviaanskloof Mega-Reserve, Eastern Cape, South Africa: A travel cost analysis using count data models. Journal of Outdoor Recreation and Tourism, 15, 47-54.

Duboeuf, T. (2006). Local power and land-use strategies in mountain resorts: sustainability of local tourism development and the challenges of governance. Revue de Géographie Alpine, 94(1), 33-51.

Duglio, S., \& Beltramo, R. (2017). Estimating the economic impacts of a small-scale sport tourism event: The case of the ItaloSwiss mountain trail CollonTrek. Sustainability, 9(3), 1-17.

Escorcia-Otálora, T. A., \& Poutou-Piñales, R. A. (2008). Análisis bibliométrico de los artículos originales publicados en la revista Universitas Scientiarum (19872007). Universitas Scientiarum, 13(3), 236-244.

Flognfeldt, T., \& Tjørve, E. (2013). The Shift from Hotels and Lodges to Second-Home Villages in Mountain-Resort Accommodation. Scandinavian Journal of Hospitality and Tourism, 13(4), 332-352.

Fredman, P. (2008). Determinants of visitor expenditures in mountain tourism. Tourism Economics, 14(2), 297-311.
Fredman, P., \& Heberlein, T. A. (2005). Visits to the Swedish mountains: Constraints and motivations. Scandinavian Journal of Hospitality and Tourism, 5(3), 177-192.

Fredman, P., \& Tyrväinen, L. (2010). Frontiers in Nature-Based Tourism. Scandinavian Journal of Hospitality and Tourism, 10(3), 177-189.

Frochot, I., Elliot, S., \& Kreziak, D. (2017). Digging deep into the experience-flow and immersion patterns in a mountain holiday. International Journal of Culture, Tourism and Hospitality Research, 11(1), 81-91.

Frosch, R., \& Elsasser, H. (1989). Actual trends in tourism planning in the Swiss Alps. Berichte zur Raumforschung und Raumplanung, 33(6), 18-29.

Fuchs, M., Höpken, W., \& Lexhagen, M. (2014). Big data analytics for knowledge generation in tourism destinations-A case from Sweden. Journal of Destination Marketing \& Management, 3(4), 198-209.

Galvani, A. (1993). Mountain tourism in cortina d'ampezzo sustainability and saturation. Tourism Recreation Research, 18(1), 2732.

Garavaglia, V., Diolaiuti, G., Smiraglia, C., Pasquale, V., \& Pelfini, M. (2012). Evaluating tourist perception of environmental changes as a contribution to managing natural resources in glacierized areas: A case study of the Forni Glacier National Park, Italian Alps. Environmental Management, 50(6), 11251138.

Gaudard, G. (1995). The opportunities and risks of tourism in the Swiss mid-altitude mountain areas. Revue de Geographie Alpine, 83(3), 51-64.

Gavel, Y., \& Iselid, L. (2008). Web of Science and Scopus: a journal title overlap study. Online Information Review, 32(1), 8-21.

Gazzola, P., Pavione, E., Grechi, D., \& Ossola, P. (2018). Cycle Tourism as a Driver for the Sustainable Development of LittleKnown or Remote Territories: The Experience of the Apennine Regions of Northern Italy. Sustainability, 10(6), 1-19.

George-Marcelpoil, E., \& Francois, H. (2012). From creating to managing resorts Emerging stakeholder group rationales in the Tarentaise valley. Revue de 
Geographie Alpine - Journal of Alpine Research, 100(1-4), 488-501.

Gluck, M. (1990). A review of journal coverage overlap with an extension to the definition of overlap. Journal of the American Society for Information Science, 41(1), 4360.

Godde, P., Price, M., \& Zimmermann, F. (2000). Tourism and Development in Mountain Regions: Moving Forward into the New Millennium. London: CABI Publishing.

Gonzalez, R., Otero, A., Nakayama, L., \& Marioni, S. (2009). Tourism mobilities and amenity migration: Problems and contradictions in the development of mountain tourism centers. Revista de Geografia Norte Grande, (44), 75-92.

Gozalo, A. (2016). El turismo deportivo como una oportunidad para los destinos de montaña. Paper presented at the IX Congreso Internacional de Turismo de Nieve y Montaña, 2- 4, March 2016, San Juliá de Lòira (Andorra).

Gurung CP, \& DeCoursey MA. (2000). Too much too fast: lessons from Nepal's Lost Kingdom of Mustang. In: Godde PM, Price MF, Zimmermann FM. (eds) (2000). Tourism and development in mountain regions. Wallingford: $\mathrm{CABI}$ Publishing, $\mathrm{p}$. 239-54.

Hadzhinikolov, D. (1982). The development of Borovets as an international centre for mountain tourism (Bulgaria). Geografija, 37(8), 5-7.

Harzing, A., \& Alakangas, S. (2016). Google Scholar, Scopus and the Web of Science: a longitudinal and cross-disciplinary comparison. Scientometrics, 106(2), 787804.

Heberlein, T. A., Fredman, P., \& Vuorio, T. (2002). Current tourism patterns in the Swedish mountain region. Mountain Research and Development, 22(2), 142149.

Herbin, J. (1986). New mountain area policy and the new social statute for mountain dwellers in France. Beitrage zur Angewandten Sozialgeographie (Augsburg), 12, 31-42.

Hubert, J. (1981). General bibliometric models. Illinois: Library Trends.
Ikenaga, M. (1999). The Development of Mountain Tourism and the Activities of Mountain Farmers in the Austrian Alps. Japanese Journal of Human Geography, 51(6), 598-615.

Ikenaga, M. (2001). The Transition of Alpine Pasture Management and the Development of Ecotourism in Hinterhornbach Village, Tyrol, in the Austrian Alps. Japanese Journal of Human Geography, 53(6), 48-65.

Jafari, J. (2003). The Encylopedia of Tourism. London: Routledge.

Kaltenborn, B., Andersen, O., Nellemann, C., Bjerke, T., \& Thrane, C. (2008). Resident attitudes towards mountain second-home tourism development in Norway: The effects of environmental attitudes. Journal of Sustainable Tourism, 16(6), 664-680.

Kelly, J., Williams, P. W., Schieven, A., \& Dunn, I. (2006). Toward a destination visitor attendance estimation model: Whistler, British Columbia, Canada. Journal of Travel Research, 44(4), 449456.

Koemle, D. B., \& Morawetz, U. B. (2016). Improving mountain bike trails in Austria: An assessment of trail preferences and benefits from trail features using choice experiments. Journal of Outdoor Recreation and Tourism, 15, 55-65.

Kohler, T., Elizbarashvili, N., Meladze, G., Svanadze, D., \& Meessen, H. (2017). The Demogeographic Crisis in Racha, Georgia: Depopulation in the Central Caucasus Mountains. Mountain Research and Development, 37(4), 415-424.

Kortoci, Y., \& Kortoci, M. (2017). The assessment of the rural tourism development in the Valbona Valley National Park. Tourism Economics, 23(8), 1662-1672.

Krištofić, B. (2010). Landscape with Capital in the Background about Actors of Change in Rural Areas-Municipality of Lovinac. Sociologija i Prostor, 48(2), 273-300.

Kuščer, K. (2013). Determining factors of mountain destination innovativeness. Journal of Vacation Marketing, 19(1), 41-54.

Kuščer, K., Mihalič, T., \& Pechlaner, H. (2017). Innovation, sustainable tourism and environments in mountain destination 
Río-Rama, M., C. Maldonado-Erazo, A. Durán-Sánchez and J. Álvarez-García (2019) / European Journal of Tourism Research 22, pp. 130-150

development: A comparative analysis of Austria, Slovenia and Switzerland. Journal of Sustainable Tourism, 25(4), 489-504.

Lasanta, T., Arnáez, J., \& Bellido, N. (2014). The contribution of a small ski resort to the development of its surrounding area: The case of Valdezcaray (La Rioja). Cuadernos de Turismo, (33), 151-172.

Lasanta, T., Laguna, M., \& Vicente-Serrano, S. M. (2007). Do tourism-based ski resorts contribute to the homogeneous development of the Mediterranean mountains? A case study in the Central Spanish Pyrenees. Tourism Management, 28(5), 1326-1339.

Lepovitz, H. (1989). Gateway to the mountains: Tourism and positive deindustrialization in the Bavarian Alps. German History, 7(3), 293-318.

Lichtenberger, E. (1979). Abandonment of high mountain areas in Europe. Recherches de Geographie rurale: hommage au Professeur Frans Dussart, (Bulletin, Societe de Geographie de Liege, numero hors serie, vol. 1), 379-400.

Linde, J., \& Grab, S. (2008). Regional contrasts in mountain tourism development in the Drakensberg, South Africa. Mountain Research and Development, 28(1), 65-71.

Loibl, W., \& Walz, A. (2010). Generic regional development strategies from local stakeholders' scenarios-an alpine village experience. Ecology and Society, 15(3).

Lotka, A.J. (1926). The frequency distribution of scientific productivity. Journal of the Washington Academy of Sciences, 16(12), 317-323.

Luthe, T., \& Schläpfer, F. (2011). Effects of third-party information on the demand for more sustainable consumption: A choice experiment on the transition of winter tourism. Environmental Innovation and Societal Transitions, 1(2), 234-254.

Luthe, T., Wyss, R., \& Schuckert, M. (2012). Network governance and regional resilience to climate change: empirical evidence from mountain tourism communities in the Swiss Gotthard region. Regional Environmental Change, 12(4), 839-854.

Macchiavelli, A. (2009). Alpine tourism. Development contradictions and conditions for innovation. Journal of Alpine
Research-Revue de Géographie Alpine, 97(1), 99-115.

Marín-Yaseli, M., \& Martínez, T. (2003). Competing for meadows: A case study on tourism and livestock farming in the Spanish Pyrenees. Mountain Research and Development, 23(2), 169-176.

Maroudas, L., Kyriakaki, A., \& Gouvis, D. (2004). A community approach to mountain adventure tourism development. Anatolia, 15(1), 5-18.

Martín Vega, A. (1995). Fuentes de Información General. Gijón: Trea.

Mazuel, L. (1992). Scale of reference and tourism promotion. Des regions paysannes aux espaces fragiles, 543-548.

Mechukaev, A., \& Mechukaev, A. (2006). Analysis of accidental deaths in mountain tourism and sport according to statistics from the Republic of Kabardino-Balkariia. Sudebno-meditsinskaia Ekspertiza, 49(4), 10-14.

Messerli, B., \& Ives, J. (1997). Mountains of the World: A Global Priority. Carnforth: Parthenon.

Meyer, D. E., Mehlman, D. W., Reeves, E. S., Origoni, R. B., Evans, D., \& Sellers, D. W. (1983). Comparison study of overlap among 21 scientific databases in searching pesticide information. Online Review, 7(1), 33-43.

Milman, A., \& Zehrer, A. (2018). Exploring visitor experience at a mountain attraction: The Nordkette Mountain in Tirol, Austria. Journal of Vacation Marketing, 24(2), 172-186.

Milman, A., Zehrer, A., \& Tasci, A. D. (2017). Measuring the components of visitor experience on a mountain attraction: the case of the Nordkette, Tyrol, Austria. Tourism Review, 72(4), 429-447.

Minciu, R., Lefter, G., \& Busuioc, M. F. (2009). Comparative analysis for mountain tourism for winter sports played in Poiana Brasov and Innsbruck. Metalurgia International, 14(15), 34-38.

Mohd Taher, S.H., Jamal, S. A., Sumarjan, N., \& Aminudin, N. (2015). Examining the structural relations among hikers' assessment of pull-factors, satisfaction and revisit intentions: The case of mountain tourism in Malaysia. Journal of 
Outdoor Recreation and Tourism, (12), 82-88.

Morrison, C., \& Pickering, C. M. (2013). Perceptions of climate change impacts, adaptation and limits to adaption in the Australian Alps: the ski-tourism industry and key stakeholders. Journal of Sustainable Tourism, 21(2), 173-191.

Moss LAG, \& Godde PM. (2000). Strategy for future mountain tourism. In: Godde PM, Price MF, Zimmermann FM, editors. Tourism and development in mountain regions. Wallingford: CABI Publishing, $\mathrm{p}$. 323-38.

Muhar, A., Schauppenlehner, T., Brandenburg, C., \& Arnberger, A. (2007). Alpine summer tourism: the mountaineers' perspective and consequences for tourism strategies in Austria. Forest Snow and Landscape Research, 81(7), 7-17.

Nepal, S. K., \& Chipeniuk, R. (2005). Mountain tourism: Toward a conceptual framework. Tourism Geographies, 7(3), 313-333.

Nicolae, N., \& Florin, B. M. (2009). Analysis of tourist traffic in the area of Prahova ValleyBrasov. Metalurgia International, 14(8), 517.

Nikolić, Đ., Spasić, J., Živković, Ž., Đorđević, P., Mihajlović, I., \& Kangas, J. (2015). SWOT-AHP model for prioritzation of strategies of the resort Stara Planina. Serbian Journal of Management, 10(2), 141-150.

Nistor, R., Nistor, C., \& Muntean, M. (2010). Tyrolean management can be applied in Romanian mountain tourism. WSEAS Transactions on Business and Economics, 7(4), 392-401.

Ortner, S. (2001). Life and Death on Mt. Everest: Sherpas and Himalayan Mountaineering. Princeton: Princeton University Press.

Palomo, I. (2017). Climate change impacts on ecosystem services in high mountain areas: A literature review. Mountain Research and Development, 37(2), 179187.

Paunović, I., \& Jovanović, V. (2017). Implementation of Sustainable Tourism in the German Alps: A Case Study. Sustainability, 9(2), 1-15.

Pawłowska, A., Matoga, Ł., \& Stach, E. (2015). The use of information and communication technologies (ICTs) in tourist information and promotion of the Polish Carpathians in foreign tourism markets. Journal of Travel \& Tourism Marketing, 32(5), 554-577.

Penz, H. (1984). Position and functional change of high mountain pastures in Tyrol and in the Trentino. Beitrage zur vergleichenden Kulturgeographie der Hochgebirge, 305-325.

Petit, J. (2002). Politique des déplacements et développement touristique; contraintes et innovations dans les vallées touristiques alpines. Revue de Géographie Alpine, 90(1), 49-66.

Pickering, C. M., \& Buckley, R. C. (2010). Climate response by the ski industry: The shortcomings of snowmaking for Australian resorts. Ambio, 39(5-6), 430438.

Price, D. D. S. (1976). A general theory of bibliometric and other cumulative advantage processes. Journal of the Association for Information Science and Technology, 27(5), 292-306.

Price, M. F. (1992). Patterns of the development of tourism in mountain environments. GeoJournal, 27(1), 87-96.

Pröbstl-Haider, U., Dabrowska, K., \& Haider, W. (2016). Risk perception and preferences of mountain tourists in light of glacial retreat and permafrost degradation in the Austrian Alps. Journal of Outdoor Recreation and Tourism, 13, 66-78.

Pronello, C., \& Camusso, C. (2017). Users' needs and business models for a sustainable mobility information network in the Alpine Space. Transportation Research Procedia, 25, 3590-3605.

Pulgarín, A., \& Escalona, M. (2008). Medidas del solapamiento en tres bases de datos con información sobre ingeniería. Anales de Documentación, 10, 335-344.

Rakytova, I., \& Tomcikova, I. (2017). Assessing sustainability in mountain tourism of Demanovska Valley, Slovakia. European Journal of Geography, 8(2), 1-18.

Ritter, F., Fiebig, M., \& Muhar, A. (2012). Impacts of global warming on mountaineering: A classification of phenomena affecting the alpine trail network. Mountain Research and Development, 32(1), 4-15. 
Río-Rama, M., C. Maldonado-Erazo, A. Durán-Sánchez and J. Álvarez-García (2019) / European Journal of Tourism Research 22, pp. 130-150

Ritter, F., Muhar, A., \& Fiebig, M. (2010). Transdisciplinary dialogue: Expert and experiential knowledge in a discourse on summer mountain tourism and climate change. GAIA, 19(3), 194-203.

Rodriguez, J. (2012). Hydropower landscapes and tourism development in the Pyrenees From natural resource to cultural heritage. Revue de Geographie Alpine - Journal od Alpine Research, 100(1-4), 289-303.

Saz Gil, M., \& Carus Ribalaygua, L. (2008). Sustainability of high-mount ain recreation tourism. Cuadernos de Desarrollo Rural, 5(60), 11-36.

Scott, D., Jones, B., \& Konopek, J. (2007). Implications of climate and environmental change for nature-based tourism in the Canadian Rocky Mountains: A case study of Waterton Lakes National Park. Tourism Management, 28(2), 570-579.

Semerdzhiev, D., \& Dancheva, T. (1984). Appreciation of the natural potential for the development of tourism in Bulgaria. Geografija, 4, 1-4.

Silva, C., Kastenholz, E., \& Abrantes, J. L. (2013). Place-attachment, destination image and impacts of tourism in mountain destinations. Anatolia, 24(1), 17-29.

Skenderovic, I., Kalac, B., \& Samardzic, M. (2012). Geographical basis of economic development in Rozaje environment. Technics Technologies Education Management, 7(3), 1072-1082.

Spanish Tourism Institute (2009). Studies of tourist products: Mountain tourism. Madrid: Spanish Tourism Institure (Turespaña).

Spinak, E. (1996). Diccionario enciclopédico de bibliometría, cienciometría e informetría. Caracas: UNESCO CII/II.

Srđan, M., \& Marija, M. (2017). Retrospective of and prospects for the development and strategic planning of tourism in the mountain regions of Serbia. Spatium, 2017(37), 42-48.

Stadelbauer, J. (1983). High mountain tourism in the Soviet Union. Development, forms and problems concerning the Great Caucasus. Erdkunde, 37(3), 199-212.

Stojsavljević, R., Božić, S., Kovačević, M., Bubalo-Živković, M., \& Miljković, Đ. (2016). Influence of selected climate parameters on tourist traffic of Kopaonik and Zlatibor mountains (Republic of
Serbia). Geographica Pannonica, 20(4), 208-219.

Storch, I., \& Leidenberger, C. (2003). Tourism, mountain huts and distribution of corvids in the Bavarian Alps, Germany. Wildlife Biology, 9(4), 301-308.

Strobl, A., Teichmann, K., \& Peters, M. (2015). Do mountain tourists demand ecotourism? Examining moderating influences in an Alpine tourism context. Turizam: Međunarodni Znanstveno-Stručni Časopis, 63(3), 383-398.

Suarez Botas, G. (2016). Historical Lodgings around the Sanctuary of Covadonga in Asturias. Lino - Revista Anual de Historia del Arte, (22), 73-87.

Swarbrooke, J., Beard, C., Leckie, S., \& Pomfret, G. (2003). Adventure tourism: The new frontier. Burlington: Butterworth Heinemann.

Tchistiakova, E., \& Cabanne, C. (1997). Urban tourism and rural tourism in Russia. Norois, 176, 571-583.

Tigu, G. (2012). New challenges for tourism destination management in Romania. In Murat, K. and Handan, A. (eds) (2012). Strategies for Tourism Industry-Micro and Macro Perspectives. London, United Kingdom: InTechOpen, 167-184

Timotin, V., Tudorache, D., \& Sârbu, R. (2009). Tourism forms on the territory of the future fagaras national park and their relation with ecotourism. Metalurgia International, 14(17), 95-98.

Tizzoni, E. (2015). Competitive branding policies for medium mountain tourism destinations: a case study from the Val di Sole (Trento). Almatourism-Journal of Tourism, Culture and Territorial Development, 6(12), 63-80.

Tofan, G. B., \& Niţă, A. (2014). Some Actual Aspects about the Tourism Accomodation in Harghita County. GeoJournal of Tourism and Geosites, 14(2), 158-167.

Tonkin, L. (1995). Can community action groups produce structural change in the Blue Mountains tourism industry? Geographical Research, 33(2), 287-298.

Tsiaras, S. (2017). Exploring the Impact of Tourism to the Sustainable Development of Mountain Regions: Implications of the Climatic Conditions. International Journal 
of Agricultural and Environmental Information Systems, 8(1), 14-28.

Tsiaras, S., \& Andreopoulou, Z. (2015). Sustainable development perspectives in a less favoured area of Greece. Journal of Environmental Protection and Ecology, 16(1), 164-172.

Tvrtko-Opačić, V., \& Banda, A. (2018). Alternative forms of tourism in mountain tourism destination: A case study of Bjelašnica (Bosnia and Herzegovina). Geographica Pannonica, 22(1), 40-53.

UNEP/PNUMA (2007). Tourism and Mountains: A Practical Guide to Managing the Environmental and Social Impacts of Mountain Tours United Nations Environment Programme. URL: http://wedocs.unep.org/handle/20.500.118 22/7687 [Accessed on 01/06/2018].

UNWTO (2017). 3rd Euro-Asian Mountain Resorts Conference. URL: http://www2 .unwto.org/event/3rd-euro-asian-mountainresorts-conference. [Accessed on 01/06/2018]

Varley, P., \& Medway, D. (2011). Ecosophy and tourism: Rethinking a mountain resort. Tourism Management, 32(4), 902-911.

Vlad, S., \& Truti, S. (1984). On mountain tourism in Romania with a special view on the Apuseni Mountains. Studii si Cercetari de Geologie, Geofizica, Geografie: Geografie, 31, 85-88.
WTO (2005). Tourism's potential as a sustainable development strategy. World Tourism Organization. Madrid: World Tourism Organization.

Whitlock, W., Van Romer, K., \& Becker, R. (1991). Nature Based Tourism: An Annotated Bibliography. Clemson: Strom Worldwide Journeys and Expeditions.

Wyss, R., Abegg, B., \& Luthe, T. (2014). Perceptions of climate change in a tourism governance context. Tourism Management Perspectives, 11, 69-76.

Younes, Y., Garcia, X.F., \& Gagneur, J. (2002). Study of the mountain tourism impact on water quality and assemblage of macrobenthic populations in the Andorran rivers. Revue des Sciences de l'Eau, 15(1), 421-424.

Zhang, Y. L., Zhang, J., Zhang, H. O., Zhang, R. Y., Wang, Y., Guo, Y. R., \& Wei, Z. C. (2017). Residents' environmental conservation behaviour in the mountain tourism destinations in China: Case studies of Jiuzhaigou and Mount Qingcheng. Journal of Mountain Science, 14(12), 2555-2567.

Zhou, L., \& Liu, J. (2017). Determining an appropriate integrated assessment model of tourism safety risk within the Changbai Mountain Scenic Area. In IOP Conference Series: Earth and Environmental Science (Vol. 59, No. 1, p. 012028). Bristol, United Kingdom: IOP Publishing. 